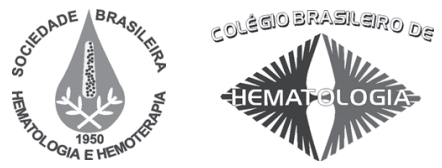

Review / Revisão

\title{
Adult acute lymphoblastic leukemia
}

\section{Leucemia linfoblástica do adulto}

Robin Foà

Sabina Chiaretti

Anna Guarini

Antonella Vitale

\begin{abstract}
This review focuses on the most recent advances in the diagnostic and prognostic workup of adult acute lymphoblastic leukemia (ALL), and on their implications in the clinical management of the disease. Over the years, information obtained through extensive immunophenotyping, karyotyping, molecular genetics, multidrug resistance and, more recently, genomic profiling is progressively contributing to a better understanding of the biology of this complex disease, to the identification of subgroups of patients with different clinical outcomes, to a more precise monitoring of minimal residual disease, to the use of different therapeutic protocols based on prognostic indicators and, finally, to the design of innovative and specific treatment strategies. The next few years will tell us if this biologically-guided approach, which is progressively individualizing the management of adult ALL patients, will ultimately impact on the prognosis of a disease that has stagnated over many decade. Rev. Bras. Hematol. Hemoter. 2009;31(Supl. 2):41-47.
\end{abstract}

Key words: Acute lymphoblastic leukemia; chemotherapy;prognostic factors.

\section{Introduction}

Adult acute lymphoblastic leukemia (ALL) represents a biologically and clinically heterogeneous group of diseases characterized by the abnormal proliferation and accumulation of immature lymphoid cells within the bone marrow and lymphoid tissues. Increasing evidence suggests that chromosomal defects and molecular abnormalities are consistently present in patients with ALL, and progress in our understanding of the biological and genetic characteristics of ALL has not only improved our knowledge of leukemogenesis, but has also allowed the identification of prognostic groups with specific cellular and molecular features. For all newly diagnosed cases of ALL, a broad and integrated biological work-up, which includes immunologic, cytogenetic and molecular analysis, and seeks to identify the prognostic factors is needed as is the definition of suitable markers for the monitoring of minimal residual disease (MRD) during the course of the disease and to design therapeutic strategies tailored according to the biological characteristics of the leukemic cells..$^{1-7}$

\section{Diagnosis}

Currently, the diagnosis and classification of ALL is a multistep procedure that relies on the simultaneous application of several techniques that investigate: morphology, cytochemistry, immunophenotype, cytogenetics, molecular genetics, immunoglobulin (Ig) and T-cell receptor (TCR) gene rearrangements and genomic profiling, as an integrated research effort. ${ }^{8,9}$

\section{Morphology and immunophenotype}

According to the French-American-British (FAB) cooperative group classification system, ${ }^{10} \mathrm{ALL}$ is characterized by the presence of more than $30 \%$ of lymphoblasts in the bone marrow (BM), while the World Health Organization (WHO) classification scheme ${ }^{11}$ established the cut-off at $20 \%$. No specific morphologic/cytochemical tests are exclusive for ALL; however, by definition, ALL is negative for myeloperoxidase (MPO) both by cytochemistry and by antiMPO monoclonal antibody (MoAb) staining.

Division of Hematology, Department of Cellular Biotechnologies and Hematology, "La Sapienza" University, Rome, Italy.

Correspondence: Robin Foà

Division of Hematology, Department of Cellular Biotechnologies and Hematology

Via Benevento 6

00161 - Rome, Italy.

Phone: +39-06-85795753 - Fax: +39-06-85795792

E-mail:rfoa@bce.uniroma1.it 
The immunophenotype is an essential component in the initial diagnostic work-up of ALL and is also a valuable tool for monitoring disease during treatment and thus for the detection of MRD. ${ }^{12,13}$ The immunophenotypic characterization of blast cells at presentation has several objectives: a) lineage assignment, b) evaluation of cell maturation, and c) assessment of phenotypic aberrations. Flow cytometry is a powerful technique for the characterization of normal and neoplastic hematopoietic cells. ${ }^{14}$ The use of highly specific MoAbs capable of recognizing distinct epitopes of surface and intracellular antigens has improved the definition of the origin and level of differentiation of acute leukemias. It is customary to report percentage of blasts expressing each antigen tested and to consider any marker present on more than $20 \%$ of blasts as positive: the cut-off level of $20 \%$ is arbitrary, however.

A panel of antibodies is needed to establish the diagnosis (Table 1) and to distinguish among the immunological subclasses. The scoring system proposed by the European Group for the Immunological Characterization of Leukemia (EGIL) ${ }^{15}$ classified acute leukemias as B- or T-lineage ALL, or as acute myeloid leukemia (AML) by including the most specific markers of the lymphoid and myeloid lineage among those of early stages of differentiation, plus some non-specific but stem cell-associated markers. On the basis of these immunophenotypic analyses, a firm diagnosis can be made in $99 \%$ of cases. About $75 \%$ of cases of adult ALL are of B-cell lineage and $25 \%$ of T-cell lineage. Although the affiliation of ALL to the B- or T-cell lineage is relatively easy, a few cases remain difficult to classify as ALL or AML; these cases co-express lymphoid and myeloid antigens, either on the same cells (biphenotypic leukemia) or on two different populations (hybrid leukemia). There is no consensus regarding the diagnostic criteria for such cases. The EGIL group has suggested the use of a scoring system based on different combinations of $\mathrm{B}, \mathrm{T}$ and myeloid antigen expressions. According to a strict scoring system, four groups can be identified; the most common group is that in which the blasts co-express myeloid and B-lymphoid antigens, and less commonly myeloid and T-lymphoid antigens. Cases co-

Table 1. Panel of markers to characterize ALL

\begin{tabular}{cc}
\hline 1st screening approach & \\
B lymphoid & CD19, cyCD22, CD79a, CD10 \\
T lymphoid & cyCD3, CD2, CD7 \\
Myeloid & anti-MPO, CD13, CD33, CD45, CD11 \\
Non-lineage specific & TdT, CD34, HLA-DR \\
\hline 2nd screening approach & \\
If B-lineage ALL & cylgM, kappa, lambda, CD20, CD24 \\
If T-lineage ALL & CD1a, sCD3, CD4, CD5, CD8, \\
& Anti-TCR $\alpha / \beta$, \\
& anti-TCR $\gamma / \delta$
\end{tabular}

expressing T- and B-lymphoid markers and those with trilineage differentiation are rare.

Another point to consider in leukemia immunophenotyping is the intensity of antigen expression; as differences in fluorescent intensity may be important in distinguishing leukemic cells from normal cells and in discriminating among subtypes of leukemia, quantitative flow cytometry (QFCM) may now be used to more objectively measure antigen-binding sites on cells; this approach may be useful both at diagnosis and during the monitoring of MRD. Moreover, the quantification of the level of expression of given antigens on the leukemic population may have therapeutic implications. MoAbs have, in fact, reached clinical utilization in ALL; this relates in particular to antibodies directed against the CD20, CD22, CD33 and CD52 antigens. ${ }^{16,17}$ Thus, the percent of positivity and the degree of expression by the leukemic population at diagnosis and at relapse is important when considering the potential clinical utilization of such antibodies for the management of ALL patients.

A variable proportion of ALL express non-lineage associated markers, e.g. myeloid antigens and CD34. The reported incidence of adult ALL showing myeloid antigen expression (My+ALL) ranges from $15 \%$ to $50 \%$, while it varies from $4 \%$ to $35 \%$ in children; the presence of these MyAg can be useful in the immunological monitoring of MRD. ${ }^{18}$

\section{Cytogenetic and molecular analyses}

Cytogenetic and molecular analyses are important to identify prognostic markers in ALL. The study of cytogenetic abnormalities is the basis for unraveling molecular events that may be involved in the disease, such as fusion transcripts that derive from translocations, tumor suppressor genes from deletions, and the control of cell cycle regulatory genes. ${ }^{1,2,4,19-22}$ Conventional cytogenetics, fluorescence in situ hybridization (FISH), comparative genomic hybridization (CGH), spectral karyotyping (SKY) analyses for chromosomal investigations, reversetranscriptase and real-time polymerase chain reactions (PCR) for molecular analyses, among other techniques, have allowed the identification of precise chromosomal and molecular defects in ALL. ${ }^{23-25}$ The detection of chromosomal abnormalities by classic karyotypic analysis or by molecular techniques has its advantages and inconveniences: only through a karyotypic analysis can an overall evaluation of the whole genome be carried out and the results obtained can direct further investigations. On the contrary, molecular techniques allow the identification of specific abnormalities in situations where karyotyping is difficult (e.g. insufficient metaphases or detection of submicroscopic abnormalities). The chromosomal abnormalities in ALL can be categorized as numerical or structural, with or without numerical abnormalities. Hyperdiploidy is the gain of additional chromosomes so that the total number of chromosomes in a 
single cell exceeds 46. In ALL, this process seems to be nonrandom. Hyperdiploidy is seen in $15 \%$ of cases of adult ALL and the association with a favorable outcome is less obvious than in childhood ALL, where it occurs in about one third of cases. Hypodiploidy (chromosomes $<46$ ) is found in $2.8 \%$ of cases of ALL and is associated with a poorer outcome. The majority of chromosomal abnormalities found in ALL are structural, usually translocations. More than 30 different nonrandom translocations have been identified in ALL. As only a relatively limited number of patients have so far been studied and many of these translocations are uncommon, the prognostic implications for most of them have still to be conclusively defined. Most of the more common karyotypic structural rearrangements have been studied at the molecular level. In molecular terms, chromosomal abnormalities or their submicroscopic equivalents are of two general types: those in which the breakpoint occurs within the involved genes leading to the production of a fusion RNA transcript and a chimeric protein (qualitative change), and those which represent Ig/ TCR rearrangement errors (quantitative change). Qualitative abnormalities produce functional fusion genes: the most common is the $\mathrm{t}(9 ; 22) \mathrm{q}(34 ; \mathrm{q} 11)$ translocation which forms the $B C R-A B L$ fusion gene; another is the $\mathrm{t}(1 ; 19) \mathrm{q}(23 ; \mathrm{p}(13)$ translocation, where the $E 2 A$ gene fuses with $P B X 1$. The rearrangement involving the $M L L$ gene on chromosome 11 in the q23 region results in a fusion gene with $A F 4$ on chromosome 4q21; furthermore, several different partners can fuse to the MLL gene. Quantitative abnormalities result from $\mathrm{Ig} / \mathrm{TCR}$ rearrangement errors which juxtapose the proto-oncogene to regulatory Ig/TCR sequences, leading to deregulated protein expression, for example the SIL-TAL1/ tald deletions on chromosome 1p32 in T-ALL. Qualitative fusion transcripts predominate in B-lineage ALL and recombinant errors are rare; in contrast, they are much more frequent in T-ALL, where they represent the majority of molecular abnormalities. Other lesions recently identified in T-ALL include Notch1 and JAK1 mutations, TLX1 (HOX11), TLX3 (HOX11L2), TAL1 and LYL1 overexpression, and ABL1 rearrangements. ${ }^{26}$ Intriguingly, the role of mutations of the JAK genes (JAK1, JAK2 and JAK3) is emerging in ALL, since JAK2 mutations were recently described in B-lineage ALL;27 this finding has obvious potential therapeutic implications, in light of the available JAK2 inhibitors.

A list of the main molecular genetic abnormalities identified in ALL and currently used for molecular diagnosis is reported in Table 2, even if this list is not exhaustive and represents a compromise between the current most appropriate molecular method to detect or exclude an abnormality and the most widely used technique.

Table 2. Main genetic abnormalities in ALL

\begin{tabular}{|c|c|c|c|c|}
\hline Disease & Abnormality & Genes involved & Incidence & Molecular detection \\
\hline \multirow{7}{*}{ B-ALL } & $t(9 ; 22)(q 34 ; q 11)$ & BCR ABL & $\begin{array}{l}\text { Adults: } 30 \% \\
\text { Children: } 3 \%\end{array}$ & RT-PCR \\
\hline & $t(12 ; 21)(p 13 ; q 22)$ & TEL AML1 & $\begin{array}{l}\text { Adults: }<1 \% \\
\text { Children: } 20 \%\end{array}$ & RT-PCR \\
\hline & $t(4 ; 11)(q 21 ; q 23)$ & MLLAF4 & $\begin{array}{l}\text { Adults: } 5 \% \\
\text { Infants: } 60 \%\end{array}$ & RT-PCR \\
\hline & $t(1 ; 19)(q 23 ; p 13)$ & E2A PBX1 & $5 \%$ & RT-PCR \\
\hline & $t(8 ; 14)(q 24 ; q 32)$ & c-MYC IgH & $1 \%$ & FISH \\
\hline & $t(17 ; 19)(q 22 ; p 13)$ & E2A HLF & $<1 \%$ & RT-PCR \\
\hline & $t(11 ; 19)(q 23 ; p 13)$ & $\begin{array}{c}\text { MLL ENL } \\
\text { JAK1/2/3 mutations }\end{array}$ & $\begin{array}{l}<1 \% \\
10 \%\end{array}$ & $\begin{array}{c}\text { RT-PCR } \\
\text { Sequencing }\end{array}$ \\
\hline \multirow{10}{*}{ T-ALL } & $\begin{array}{c}\mathrm{t}(10 ; 14)(\mathrm{q} 24 ; \mathrm{q} 11) \\
\mathrm{t}(7 ; 10)(\mathrm{q} 34 ; \mathrm{q} 24\end{array}$ & $\begin{array}{c}\text { HOX11 TCR } \alpha / \delta \\
\text { HOX11 TCR } \beta\end{array}$ & $\begin{array}{l}\text { Adults: } 31 \% \\
\text { Children: } 7 \%\end{array}$ & RT-PCR \\
\hline & $t(5 ; 14)(q 35 ; q 32)$ & $\begin{array}{l}\text { HOX11L2 } \\
\text { TCR } \beta\end{array}$ & $\begin{array}{l}\text { Adults: } 13 \% \\
\text { Children: } 20 \%\end{array}$ & RT-PCR, FISH \\
\hline & $t(1 ; 14)(p 32 ; q 11)$ & TAL1 TCR $\alpha / \delta$ & $1-3 \%$ & RT-PCR \\
\hline & Normal 1p32 & SIL TAL1 & $9-30 \%$ & RT-PCR \\
\hline & $\operatorname{inv}(7)(p 15 q 34), t(7 ; 7)$ & HOXAgenes TCR $\beta$ & $5 \%$ & FISH, RT-PCR \\
\hline & $t(10 ; 11)(p 13 ; q 14-21)$ & CALM AF10 & $10 \%$ & FISH \\
\hline & $t(9 ; 9)(q 34 ; q 34)$ & NUP214 ABL1 & $6 \%$ & FISH \\
\hline & $t(9 ; 14)(q 34 ; q 34)$ & EML1 ABL1 & $<1 \%$ & FISH \\
\hline & NOTCH1 mutations & NOTCH1 & $50 \%$ & Sequencing \\
\hline & JAK1 mutations & JAK1 & $18 \%$ & Sequencing \\
\hline
\end{tabular}


Identification of recurring cytogenetic abnormalities and molecular alterations in ALL has had a major impact on risk assessment and a number of structural and chromosomal changes have been incorporated into existing classification systems.

\section{Genome-wide approaches}

Genomic profiling is becoming a reality that may affect our approach to ALL patients. The potential exploitation of microarray analysis can be summarized in 5 points: 1) it can define the genetic signature of neoplastic populations; 2) it can define the lineage affiliation; 3 ) it can identify sets of genes that characterize subsets of patients with distinct responses to treatment and, ultimately, have a prognostic impact; 4) it may identify potential therapeutic targets; finally, 5) it may allow the identification of drug susceptibility or resistance. In both childhood and adult ALL, gene expression profiling has revealed distinct gene expression patterns in specific subtypes. ${ }^{28,29}$ Hierarchical clustering of all adult ALL samples based on gene expression profile has identified two well-defined groups, which correlate with the T- or B-cell lineage of the leukemic cells. Within B-lineage ALL, further analyses have identified gene expression profiles associated with the presence of the ALL1-AF4, BCR-ABL or E2A-PBX1 gene rearrangements. ${ }^{30}$ Remarkably, gene signatures are extremely similar between cases that harbor specific rearrangements regardless of age. Within T-lineage ALL, gene expression profiling has recently allowed the identification of specific signatures that are associated with molecularly defined aberrations, and in particular with MLL rearrangements, SIL-TAL1 aberrations, HOX11 and HOX11L2 aberrations, CALM-AF10, inv(7) and SET-NUP214; the three latter resulting in the deregulation of HOXA genes. Furthermore, in T-ALL the wide use of gene expression profiling is proving helpful in identifying a handful of distinct subsets, which may have important prognostic implications. The identification of sets of genes associated with induction treatment and overall survival highlights the role of this approach in patient stratification. In addition, gene profiling can identify genes that may be the target of specific therapeutic strategies. Finally, gene expression profiling may be useful in a diagnostic setting, as shown by the international MILE (Microarray Innovations in LEukemia) project, that enrolled more than 3000 patients with acute and chronic leukemias worldwide, and proved highly sensitive in disease classification (95.6\% median sensitivity and 99.8\% median specificity). ${ }^{31}$

Additional important findings are being seen with the use of SNP (Single Nucleotide Polymorphism) arrays, which allow the identification of copy number alterations and, in some instances, Loss of Heterozygosity (LOH). Among the lesions that have been identified using this approach, it is worth mentioning that deletions of Ikaros, that have been reported in both adults and children, are associated with BCR/ ABL1 rearrangements and with a dismal prognosis in both cohorts of patients. ${ }^{32,33}$

\section{Minimal residual disease}

One of the most important challenges in leukemia treatment is to accurately distinguish patients who require more intensive (and potentially more toxic) therapy from those for whom cure rates can be achieved with less intensive therapy. MRD studies can provide a direct measurement of the degree and rapidity of leukemic cell responses to chemotherapy and to estimate the amount of residual tumor rather than just to establish its presence; this information can be used to improve strategies of risk assessment and treatment selection in the management of ALL patients. ${ }^{34-38}$ Leukemia cells can be potentially distinguished from normal hematopoietic progenitors on the basis of morphological and cytochemical properties, immunophenotype, karyotypic or genetic abnormalities, and Ig/TCR gene rearrangements. These different characteristics have been exploited in an attempt to detect small numbers of blasts within normal cells and a variety of techniques have been developed for the detection of residual disease ${ }^{12,13,24,39}$ The greatest limitation in the routine use of MRD studies in ALL therapy protocols is that none of the techniques currently available for MRD detection can be applied to all patients. Because PCR may detect residual leukemic cells in cases not amenable to flow cytometric investigation, and vice-versa, it is possible to apply the two techniques in tandem.

In ALL, MRD can be studied utilizing techniques that enable the identification of leukemic cells with a sensitivity of $10^{3}-10^{6}$ :

1) flow-cytometric immunophenotyping, using aberrant or patient-specific phenotypes;

2) RT-PCR and RQ-PCR analysis of breakpoint fusion genes;

3) RT-PCR and RQ-PCR analysis for the detection of clone-specific Ig and/or TCR gene rearrangements.

In adult ALL, prospective studies with MRD-based risk stratification are ongoing. As in children, a very good response documented by an early and rapid decrease of MRD during induction, may be associated with a low(er) relapse risk in adult ALL patients. However, in general the decrease of MRD occurs slower in adults than in children and few patients reach a negative MRD status. Nevertheless, before using MRD data to guide therapy, further analyses are required to conclusively establish the predictive value of MRD findings.

\section{Prognostic factors}

The diagnostic methods aimed at defining ALL subgroups with a different prognostic likelihood have 
substantially broadened in recent years. ${ }^{20,34,36}$ Adult ALL are generally divided into only two groups: a standard risk group and a high-risk group. The presence of BCR-ABL and of MLL rearrangements represents a well-established unfavorable prognostic factor. At variance, there are still different issues to be clarified in a further attempt to incorporate risk stratification in adult cases: 1) the time point of risk stratification, 2) the combination of MRD and conventional risk factors, and 3) treatment decisions based on risk stratification. A useful measure in risk assessment is the rate of clearance of leukemic cells from the bone marrow during the early phase of therapy. Another approach is to use PCR or immunological methods to measure MRD soon after the induction of clinical remission. Thus, while risk classifications are today based on clinical features of patients and on the characteristics of the leukemic cells, the new risk stratification algorithm of adult ALL is more complex and is based on:

- earlier "conventional parameters", such as clinical characteristics including age, white blood cell count, organ involvement (e.g. CNS, mediastinum, extramedullary involvement);

- immunophenotype;

- cytogenetic aberrations and molecular genetics;

- monitoring of MRD.

\section{Young adult patients with ALL}

Young adult patients between 15 and 20 years of age with ALL represent a unique epidemiologic group in that they may be treated by either adult or pediatric hematologists. Recent data ${ }^{40-45}$ suggest that the outcome of this subgroup of patients is markedly improved if they are treated on intensive pediatric ALL protocols rather than on less intensive adult ALL protocols. There seems to be no significant differences in presenting clinical features, immunophenotypic characteristics, or cytogenetic abnormalities for young adult patients treated on pediatric or adult protocols. Nevertheless, adolescents treated in adult trials appear to have a significantly higher risk of treatment failure resulting, in most cases, in resistant disease. Why this occurs is still unclear; it could be explained by the different treatment modalities or differences in therapeutic practices. A reasonable strategy for this category of patients is to develop and implement age-unrestricted but disease-specific treatment protocols, or simply to utilize pediatric protocols.

\section{Conclusions}

Clearly, the overall approach to the management of ALL in all ages of life has changed remarkably over the last few years and is continuously evolving. This largely stems from advances in the biological characterization of the leukemic cells. This is gradually leading to a more targeted and individualized clinical management of patients. This has translated, among other things, into: a) an always better prognosis for younger children; $b$ ) stratification of childhood ALL based on the degree of MRD response; c) an improved outcome for adolescents and young adults treated with aggressive pediatric-like protocols; d) investigation of the use of a pediatric like approach in older adult patients (up to what age?); e) an incorporation of MRD monitoring into adult ALL protocols; f) use of tyrosine kinase inhibitors as front line treatment for $\mathrm{Ph}+\mathrm{ALL} ; \mathrm{g}$ ) the possibility of managing elderly $\mathrm{Ph}+\mathrm{ALL}$ patients with such compounds alone; h) a broader clinical use of MoAbs; i)...

It is easy to foresee that the continuous refinement of technological tools, aimed at an ever more sophisticated characterization of ALL cells, will progressively lead to an ever greater use of targeted strategies in the management of patients of all ages suffering from ALL.

\section{Resumo}

Esta revisão focaliza os mais recentes avanços no diagnóstico e prognóstico da leucemia linfoblástica aguda do adulto e suas implicações no manuseio clínico desta doença. Com o passar dos anos, informações obtidas através de extensa pesquisa em imunofenotipagem, citogenética, genética molecular, resistência a múltiplas drogas e, mais recentemente, perfil genômico têm contribuído progressivamente para o melhor entendimento da biologia desta doença complexa, na identificação de sub grupos de pacientes com evolução clínica distintas, no mais preciso monitoramento da doença residual mínima, no uso de diferentes protocolos baseados em indicadores prognósticos e, mais recentemente, também no desenho de tratamentos inovativos e especificos. Os próximos anos nos dirão se abordagens baseadas guiadas biologicamente, que será uma individualização progressiva do manuseio dos pacientes adultos com LLA podem causar um impacto favorável em uma doença estagnada há várias décadas. Rev. Bras. Hematol. Hemoter. 2009;31(Supl. 2):41-47.

Palavras-chave: Leucemia linfoblática; quimioterapia; fatores prognósticos.

\section{References}

1. Pui CH, Relling MV, Downing JR. Acute lymphoblastic leukemia. N Eng1 J Med. 2004;350(15):1535-48.

2. Randolph TR. Advances in acute lymphoblastic leukemia. Clin Lab Sci. 2004 Fall;17(4):235-45.

3. Armstrong SA, Look AT. Molecular genetics of acute lymphoblastic leukemia. J Clin Oncol. 2005;23(26):6306-15.

4. Harrison CJ, Foroni L. Cytogenetics and molecular genetics of acute lymphoblastic leukemia. Rev Clin Exp Hematol. 2002; 6(2):91-113.

5. Vitale A, Guarini A, Chiaretti S, Foà R. The changing scene of adult acute lymphoblastic leukemia. Curr Opin Oncol. 2006; 18(6):652-9.

6. Campana D, Pui CH. Detection of minimal residual disease in acute leukemia: methodologic advances and clinical significance. Blood. $1995 ; 85(6): 1416-34$. 
7. Bassan R, Gatta G, Tondini C, Willemze R. Adult acute lymphoblastic leukaemia. Crit Rev Oncol Hematol. 2004; 50(3): 223-61

8. Foa R, Vitale A. Towards an integrated classification of adult acute lymphoblastic leukemia. Rev Clin Exp Hematol. 2002; 6(2): 181-99.

9. Gökbuget N, Hoelzer D. Recent approaches in acute lymphoblastic leukemia in adults. Rev Clin Exp Hematol. 2002;6(2):114-41.

10. Bennett JM, Catovsky D, Daniel MT, Flandrin G, Galton DA, Gralnick HR, et al. Proposals for the classification of the acute leukaemias. French-American-British (FAB) co-operative group. Br J Haematol. 1976;33(4):451-8.

11. Harris NL, Jaffe ES, Diebold J, Flandrin G, Muller-Hermelink HK, Vardiman J, et al. World Health Organization classification of neoplastic diseases of the hematopoietic and lymphoid tissues: report of the Clinical Advisory Committee meetingAirlie House, Virginia, November 1997. J Clin Oncol. 1999; 17 (12):3835-49.

12. Campana D, Coustan-Smith E. Minimal residual disease studies by flow cytometry in acute leukemia. Acta Haematol. 2004;112(12):8-15.

13. Vidriales MB, San-Miguel JF, Orfao A, Coustan-Smith E, Campana D. Minimal residual disease monitoring by flow cytometry. Best Pract Res Clin Haematol. 2003;16(4):599-612.

14. Béné MC. Immunophenotyping of acute leukaemias. Immunol Lett. 2005;98(1):9-21.

15. Bene MC, Castoldi G, Knapp W, Ludwig WD, Matutes E, Orfao A, et al. Proposals for the immunological classification of acute leukemias. European Group for the Immunological Characterization of Leukemias (EGIL). Leukemia. 1995;9(10): 1783-6.

16. Nemecek ER, Matthews DC. Antibody-based therapy of human leukemia. Curr Opin Hematol. 2002;9(4):316-21.

17. Gökbuget N, Hoelzer D. Novel antibody-based therapy for acute lymphoblastic leukaemia. Best Pract Res Clin Haematol. 2006; 19(4):701-13.

18. Vitale A, Guarini A, Ariola C, Meloni G, Perbellini O, Pizzuti M, et al. Absence of prognostic impact of CD13 and/or CD33 antigen expression in adult acute lymphoblastic leukemia. Results of the GIMEMA ALL 0496 trial. Haematologica. 2007;92(3):342-8.

19. Mancini M, Scappaticci D, Cimino G, Nanni M, Derme V, Elia L, et al. A comprehensive genetic classification of adult acute lymphoblastic leukemia (ALL): analysis of the GIMEMA 0496 protocol. Blood. 2005;105(9):3434-41.

20. Moorman AV, Harrison CJ, Buck GA, Richards SM, Secker-Walker LM, Martineau M, et al. Karyotype is an independent prognostic factor in adult acute lymphoblastic leukemia (ALL): analysis of cytogenetic data from patients treated on the Medical Research Council (MRC) UKALLXII/Eastern Cooperative Oncology Group (ECOG) 2993 trial. Blood. 2007;109(8):3189-97.trial. Blood 2007; 109:3189-97.

21. Pullarkat V, Slovak ML, Kopecky KJ, Forman SJ, Appelbaum FR, et al. Impact of cytogenetics on the outcome of adult acute lymphoblastic leukemia: results of Southwest Oncology Group 9400 study. Blood. 2008;111(5):2563-72.

22. Graux C, Cools J, Michaux L, Vandenberghe P, Hagemeijer A. Cytogenetics and molecular genetics of T-cell acute lymphoblastic leukemia: from thymocyte to lymphoblast. Leukemia. 2006; 20(9):1496-510.

23. Elia L, Mancini M, Moleti L, Meloni G, Buffolino S, Krampera M, et al. A multiplex reverse transcriptase-polymerase chain reaction strategy for the diagnostic molecular screening of chimeric genes: a clinical evaluation on 170 patients with acute lymphoblastic leukemia. Haematologica. 2003;88(3):275-9.
24. van Dongen JJ, Langerak AW, Brüggemann M, Evans PA, Hummel M, Lavender FL, et al. Design and standardization of PCR primers and protocols for detection of clonal immunoglobulin and T-cell receptor gene recombinations in suspect lymphoproliferations: report of the BIOMED-2 Concerted Action BMH4-CT98-3936. Leukemia. 2003;17(12):2257-317.

25. Speicher MR, Carter NP. The new cytogenetics: blurring the boundaries with molecular biology. Nat Rev Genet. 2005; 6(10): 782-92.

26. Chiaretti S, Foà R. T-cell acute lymphoblastic leukemia. Haematologica. 2009;94(2):160-2.

27. Mullighan CG, Zhang J, Harvey RC, Collins-Underwood JR, Schulman BA, Phillips LA, et al. JAK mutations in high-risk childhood acute lymphoblastic leukemia. Proc Natl Acad Sci U S A. 2009;106(23):9414-8.

28. Yeoh EJ, Ross ME, Shurtleff SA, Williams WK, Patel D, Mahfouz $\mathrm{R}$, et al. Classification, subtype discovery, and prediction of outcome in pediatric acute lymphoblastic leukemia by gene expression profiling. Cancer Cell. 2002;1(2):133-43.

29. Haferlach T, Kohlmann A, Schnittger S, Dugas M, Hiddemann W, Kern W, et al. Global approach to the diagnosis of leukemia using gene expression profiling. Blood. 2005;106(4):1189-98.

30. Chiaretti S, Li X, Gentleman R, Vitale A, Wang KS, Mandelli F, et al. Gene expression profiles of B-lineage adult acute lymphocytic leukemia reveal genetic patterns that identify lineage derivation and distinct mechanisms of transformation. Clin Cancer Res. 2005;11(20):7209-19.

31. Haferlach T, Kohlmann A, Basso G, et al. The Clinical Utility of Microarray-Based Gene Expression Profiling in the Diagnosis and Sub-Classification of Leukemia: Final Report on 3252 Cases from the International MILE Study Group. ASH, 50th Annual Meeting, San Francisco (CA) 6-9/12/2008. Blood 2008;112, abs.753.

32. Mullighan CG, Su X, Zhang J, Radtke I, Phillips LA, Miller CB, et al. Children's Oncology Group. Deletion of IKZF1 and prognosis in acute lymphoblastic leukemia. N Engl J Med. 2009; 360(5):470-80.

33. Iacobucci I, Lonetti A, Messa F, Cilloni D, Arruga F, Ottaviani E, et al. Expression of spliced oncogenic Ikaros isoforms in Philadelphia-positive acute lymphoblastic leukemia patients treated with tyrosine kinase inhibitors: implications for a new mechanism of resistance. Blood. 2008;112(9):3847-55.

34. Mortuza FY, Papaioannou M, Moreira IM, Coyle LA, Gameiro P, Gandini $\mathrm{D}$, et al. Minimal residual disease tests provide an independent predictor of clinical outcome in adult acute lymphoblastic leukemia. J Clin Oncol. 2002;20(4):1094-104.

35. Foroni L, Hoffbrand AV. Molecular analysis of minimal residual disease in adult acute lymphoblastic leukaemia. Best Pract Res Clin Haematol. 2002;15(1):71-90.

36. Brüggemann M, Raff T, Flohr T, Gökbuget N, Nakao M, Droese J, et al. Clinical significance of minimal residual disease quantification in adult patients with standard-risk acute lymphoblastic leukemia. Blood. 2006;107(3):1116-23.

37. Krampera M, Vitale A, Vincenzi C, Perbellini O, Guarini A, Annino L, et al. Outcome prediction by immunophenotypic minimal residual disease detection in adult T-cell acute lymphoblastic leukaemia. Br J Haematol. 2003;120(1):74-9.

38. Toubai T, Tanaka J, Ota S, Fukuhara T, Hashino S, Kondo T, et al. Minimal residual disease (MRD) monitoring using rearrangement of T-cell receptor and immunoglobulin $\mathrm{H}$ gene in the treatment of adult acute lymphoblastic leukemia patients. Am J Hematol. 2005 ;80(3):181-7.

39. van der Velden VH, Boeckx N, van Wering ER, van Dongen JJ. Detection of minimal residual disease in acute leukemia. J Biol Regul Homeost Agents. 2004;18(2):146-54 
40. Boissel N, Auclerc MF, Lhéritier V, Perel Y, Thomas X, Leblanc T, et al. Should adolescents with acute lymphoblastic leukemia be treated as old children or young adults? Comparison of the French FRALLE93 and LALA-94 trials. J Clin Oncol. 2003;21(5):774-80.

41. de Bont JM, Holt B, Dekker AW, van der Does-van den Berg A, Sonneveld P, Pieters R. Significant difference in outcome for adolescents with acute lymphoblastic leukemia treated on pediatric vs adult protocols in the Netherlands. Leukemia. 2004;18(12):2032-5.

42. Testi AM, Valsecchi MG, Conter V, et al. Difference in outcome of adolescents with acute lymphoblastic leukemia (ALL) enrolled in pediatric (AIEOP) and adult (GIMEMA) multicenter protocols. Blood 2004;104:539a.

43. Nachman J. Clinical characteristics, biologic features and outcome for young adult patients with acute lymphoblastic leukaemia. Br J Haematol. 2005;130(2):166-73.

44. Schiffer CA. Differences in outcome in adolescents with acute lymphoblastic leukemia: a consequence of better regimens? Better doctors? Both? J Clin Oncol. 2003;21(5):760-1.

45. Ribera JM, Oriol A, Sanz MA, Tormo M, Fernández-Abellán P, del Potro E, et al. Comparison of the results of the treatment of adolescents and young adults with standard-risk acute lymphoblastic leukemia with the Programa Español de Tratamiento en Hematología pediatric-based protocol ALL-96. J Clin Oncol. 2008;26(11):1843-9.

O tema apresentado foi proposto pela Organização do $8^{\circ}$ Simpósio da Associação Ítalo-Brasileira de Hematologia, realizado durante o

XIII Congresso de Transplante de Medula Óssea.

Publicado após concordância do editor.

Conflito de interesse: sem conflito de interesse

Recebido: 07/07/2009

Aceito: 08/07/2009 